\title{
Confronting Islamic Jihadist Movements
}

\section{by M Afzal Upal}

\section{(cc) $\mathrm{BY}$}

This work is licensed under a Creative Commons Attribution 3.0 License

\begin{abstract}
This paper argues that in order to win the long-term fight against Islamic Jihadist movements, we must confront their ideological foundations and provide the majority of Muslims with an alternative narrative that satisfies their social identity needs for a positive esteem. By analysing social identity dynamics of Western-Muslim interactions, this paper presents some novel ideas that can lead to the creation of such a narrative.
\end{abstract}

Keywords: counter-terrorism, master narratives, counter-narratives, countering violent extremism (CVE)

\section{Introduction}

ince the attacks of September 11,2001, violent extremism originating from the Islamic world has been a concern for Western policy makers. Although their primary interest has been to prevent immediate attacks against the West and its allies, understanding the root causes of Islamic extremism and countering the ideological infrastructure of Jihad have become increasingly important to Western decision makers and researchers. Recent terrorist attacks by ISIS sympathizers in Canada, the US, the UK, Australia, and France have demonstrated the limits of a narrowly-focussed prevention strategy. Formulating an effective, broad counter-offensive that can compete against the Jihadi narrative in the war of ideas and strengthen the forces of moderate Islam has remained a challenge because of the lack of a credible alternative narrative. This article carries out a social identity theoretic analysis of Western-Islamic interactions to better understand these challenges and suggests some promising ideas for the development of an alternative narrative.

\section{History}

Islamic nations and the West have a millennia-long history of intellectual conflict and violent warfare. Crusades and colonialism are just two particularly well known milestones along this road littered with such monuments. The Muslim-Christian dialogue of conflict began within a few years after the birth of Islam-the 'newer' religion. In $636 \mathrm{CE}$, just a short fourteen years after Prophet Muhammad's death, Judeo-Christian Jerusalem succumbed to Islam's expanding influence. Within the short span of a few years all the major Christian centres of the Middle East (including Antioch, Damascus, Alexandria, and Carthage) had come under Islamic rule. There were repeated Muslim attacks against the headquarters of the Eastern Christian Church-Constantinople (which finally capitulated in 1453). Pope Gregory declared the first Crusade as a counter offensive against Muslims in 996. For the next three hundred years, the two civilizations militarily fought against each other in a broad front extending from Spain in the west to Syria in the east. As a result of the 500 year-long expansion of Islam and the resulting meteoric rise in Muslim fortunes, the Islamic myth of invincibility became widespread-especially among Muslims. "If you faithfully follow Allah and his path, 
Allah will make you victorious" became a firmly embedded as a part of Muslim identity (Akyol 2011).

The fatal blow against the Muslim expansion came from an unexpected quarter. The Mongol invasions of the thirteenth century were so ferocious that they broke through the Islamic narrative of invincibility. This was the first time the Muslims were forced to ask the question of what went wrong (Lewis 2003). What reduced this cognitive dissonance (Festinger and Schachter 1964) for most Muslims was not a revision of the belief in God's promise of victory. Instead, as the $13^{\text {th }}$ century cleric Ibn-e-Tamiyya explained, Allah had taken victory away from Muslims because they had stopped following Islam faithfully enough. The only way to restore the glory of the golden era of Islam was to go back to faithfully following Islamic tenets, in particular Jihad, argued Ibn-e-Tamiyya and others.

While the Mongol rulers themselves eventually converted to Islam, and the Ottoman Empire had some success in reuniting Muslims under one empire and making further inroads into Eastern Europe, Islamic communities never regained the degree of cultural and material dominance over the Christian West that they enjoyed in the $11^{\text {th }}$ and $12^{\text {th }}$ centuries. The myriad reasons for this include the rise of science, reason, and free thinking in Europe and its relative decline in the Islamic countries. The final insult from a Muslim perspective came with the military defeat of the Ottoman Empire, the disbanding of the Caliphate, and the colonial occupation of Muslim countries throughout Middle East, North Africa, and South and East Asia in the $19^{\text {th }}$ and early $20^{\text {th }}$ centuries. Faced with this degradation, Muslims once again turned inward and asked themselves "what went wrong." And once again, by far the most dominant answer provided was to echo Ibne-Tamiyya's $13^{\text {th }}$ century observation. "Because we stopped following Islam faithfully enough" was the answer by the South Asian scholar Abul-ala-Moudoodi and by Egyptians Syed Qutb and Hasan Al-Banna (Akyol 2011). A recent survey reveals that there is a widely-held opinion by Muslims around the world that they should adhere to the tenets of Islam more closely (PewForum 2012).

A legacy of this long history of mutual adversity is that Western countries are seen as hostile to Islam by Muslims around the world (Figure 1). When asked to identify the greatest danger to their nation, Indonesians, Pakistanis, and Malaysians chose United States as the biggest danger to their survival (PewForum 2012). A separate 2014 Pew Global Survey found that while, “... g global median of 65\% voice an affirmative opinion about America...This includes a median of 74\% in Africa, 66\% in Western Europe, 66\% in Asia, 65\% in Latin America, but just 30\% in the Middle East" (PewGlobalSurvey 2014). The lowest ratings for the US were found in the Islamic world. Table 1 shows the US favourability ratings for Islamic countries surveyed by Pew. 


\section{Journal of Terrorism Research}

\begin{tabular}{|l|l|l|}
\hline & Americans & Europeans \\
\hline $\begin{array}{l}\text { Palestinian } \\
\text { Territories }\end{array}$ & 73 & 69 \\
\hline Turkey & 72 & 70 \\
\hline Pakistan & 72 & 69 \\
\hline Egypt & 63 & 70 \\
\hline Lebanon & 59 & 49 \\
\hline Jordan & 58 & 62 \\
\hline Israel & 47 & 37 \\
\hline Indonesia & 42 & 35 \\
\hline
\end{tabular}

Figure 1: Median percentage of Muslims who perceive the Americans and Europeans as hostile to the Muslims according to a 2011 Pew Global Survey.

Andrew Kohut, directory of the Pew Research Center for People and the Press, argues that "the most serious problem facing the United States is its very poor public image in the Muslim world, especially in the Middle East/Conflict Area." (el-Nawawy 2006) In order to positively change this image, the US government launched a series of multimillion dollar programmes designed to, "improve America's image in the Middle East and win the hearts and minds of the Arab people." (el-Nawawy 2006) This included launching of Radio Sawa and Alhurra Television to broadcast in Arabic. A study by el-Nawawy (2006) found that listening to the USsponsored networks not only failed to improve Arab perceptions of the US foreign policy, but actually had the opposite effect. People's attitudes towards US foreign policy actually worsened since they started listening to Radio Sawa and watching Alhurra TV. The failure of such efforts may be due to an inability of the US programme architects to appreciate the challenges of influencing members of a target audience that considers the US to be an adversarial group seeking to corrupt their culture. 
The Centre for the Study of Terrorism and Political Violence

\section{Journal of Terrorism Research}

\begin{tabular}{|c|c|c|c|c|c|c|c|c|c|c|c|c|c|c|}
\hline & $\begin{array}{l}1999 / \\
2000\end{array}$ & 2002 & 2003 & 2004 & 2005 & 2006 & 2007 & 2008 & 2009 & 2010 & 2011 & 2012 & 2013 & 2014 \\
\hline Turkey & 52 & 30 & 15 & 30 & 23 & 12 & 9 & 12 & 14 & 17 & 10 & 15 & 21 & 19 \\
\hline Egypt & & & & & & 30 & 21 & 22 & 27 & 17 & 20 & 19 & 16 & 10 \\
\hline Jordan & & 25 & 1 & 5 & 21 & 15 & 20 & 19 & 25 & 21 & 13 & 12 & 14 & 12 \\
\hline Lebanon & & 36 & 27 & & 42 & & 47 & 51 & 55 & 52 & 49 & 48 & 47 & 41 \\
\hline Palestine & & & 0 & & & & 13 & & 15 & & 18 & & 16 & 30 \\
\hline Tunisia & & & & & & & & & & & & 45 & 42 & 42 \\
\hline $\begin{array}{l}\text { Israeli } \\
\text { Arabs }\end{array}$ & & & & & & & & & & & & & & 46 \\
\hline Bangladesh & & & & & & & & & & & & & & 76 \\
\hline Indonesia & & & & & 38 & 30 & 29 & 37 & 63 & 59 & 54 & & 61 & 59 \\
\hline Malaysia & & & & & & & 27 & & & & & & 55 & $\begin{array}{l}51 \\
\text { (among } \\
\text { Muslim } \\
\text { s 40\%) }\end{array}$ \\
\hline Pakistan & 23 & 10 & & 21 & 23 & 27 & 15 & 19 & 16 & 17 & 12 & 12 & 11 & 14 \\
\hline Morocco & & & & & & & 15 & & & & & & & \\
\hline Senegal & & & & & & & & & & & & & 81 & 74 \\
\hline
\end{tabular}

Table 1: Pew Global Attitudes Survey US Favourability Ratings in the Muslim Countries.

\section{Social Psychology of Outgroup Influences}

Social identity theory (SIT) is one of the most well developed social psychological models of group interactions including intergroup violence. (Tajfel and Turner 1985, Tajfel and Turner 1986) According to SIT, group members engage in violent collective action against an outgroup if they believe that doing so will enhance their group's status and lower the outgroup's status. In addition to violent collective action against an outgroup, groups also use seemingly non-violent strategies such as social creativity which allow them to reshape their shared beliefs so that the ingroup's status looks better when compared to the outgroup. (Hogg and Vaughan 2002) One of the social creativity strategies is to reinterpret the dimensions of comparison between groups. Ingroup members can elevate the importance of positive ingroup characteristics and downgrade those dimensions on which an outgroup looks better (van Knippenberg 1978, Mummendey and Schreiber 1984). This can sometimes produce counterintuitive and unexpected results. For instance, in comparison with dominant white Americans, African- and Latino-American status looks lower when status is computed using the dimensions of wealth and educational achievements. Some social psychologists (e.g., (Powell 2011)) argue that black ghetto culture shifts dimensions of comparison to street toughness and physical prowess because these dimensions of comparison make Black Americans from the ghetto look better relative to White Americans.

Frustrated by a social order in which ascendancy was thwarted, marginalized primarily African- and Latino-American communities invented their own alternative system in which their ruggedly countercultural personas are privileged. Encoded in its narratives, apparel, embellishments, and actual physiology, the hip-hop subculture manifests rejection of the dominant culture's systematized mores, norms, institutions, and legitimacy... devalued traits such as misogyny, hypermasculinity, and children out-of-wedlock are all imbued with in-group social value. (p. 462) (Powell 2011)

Social psychologists, such as (Taylor 2002), argue that such redefinitions are necessary to allow members of a stigmatized group to maintain a positive self-esteem which is needed for their mental well-being. Social 
psychologists also contrast social creativity (largely viewing it as positive) with violent collective action against an outgroup (largely viewing it as negative). However, cultural scientists studying strategies used by minorities to cope with their marginalization have observed that social creativity strategies often work hand in glove with violent collective action. A study of the Black American social movements by Powell (2011) shows that social creativity strategies that result in development and propagation of myths of Black ghetto males as hypermasculine tough-guys who fearlessly confront an oppressive and unjust police can also result in an increase in collective violence against the police. Powell (2011) argues that an unchallenged glorification of perceived in-group strengths can result in intense expressions of outgroup hatred such as the 1992 Ice-T hit song "Cop Killer."

A similar dynamic can be seen at work among Muslim social and religious movements. Many of these movements have their roots in the anti-colonial struggle by Muslim societies against their Western occupiers. During the colonial period, dominance of the West in material wealth and military technology became hard to deny even for the most chauvinist Muslims. Most of the creative Muslims thinkers including Sunni (Abul-ala-Moudoodi, Jalal-ul-Din Afghani, Syed Qutb, and Hasan Al-Banna), Shia (Imam Khomeini \& Sheikh Hasan Nasrallah), and heterodox (such as Mirza Ghulam Ahmad) found Muslims receptive to their social identity redefinition attempts. They argued that spirituality and family values count for more than material wealth and individual freedom and that while the West has material wealth and individual freedom, Muslims have spiritual wealth and strong family bonds. (Funk and Said 2004) As a result of at least a century of persistent redefinition efforts by Muslims social identity entrepreneurs (Haslam, Reicher et al. 2005, Upal 2005), in most of the Muslim world, Westerners are perceived to be irreligious and too focused on their pursuit of individual desires at the expense of their family's needs. Thus a 2011 Pew Global survey found that when Muslims were asked about their perceptions of the Westerners, they listed selfish, violent, greedy, and immoral as their most common perceptions. (PewGlobalAttitudesProject 2011) 


\section{Journal of Terrorism Research}

\section{What Do You Consider Yourself \\ First?}

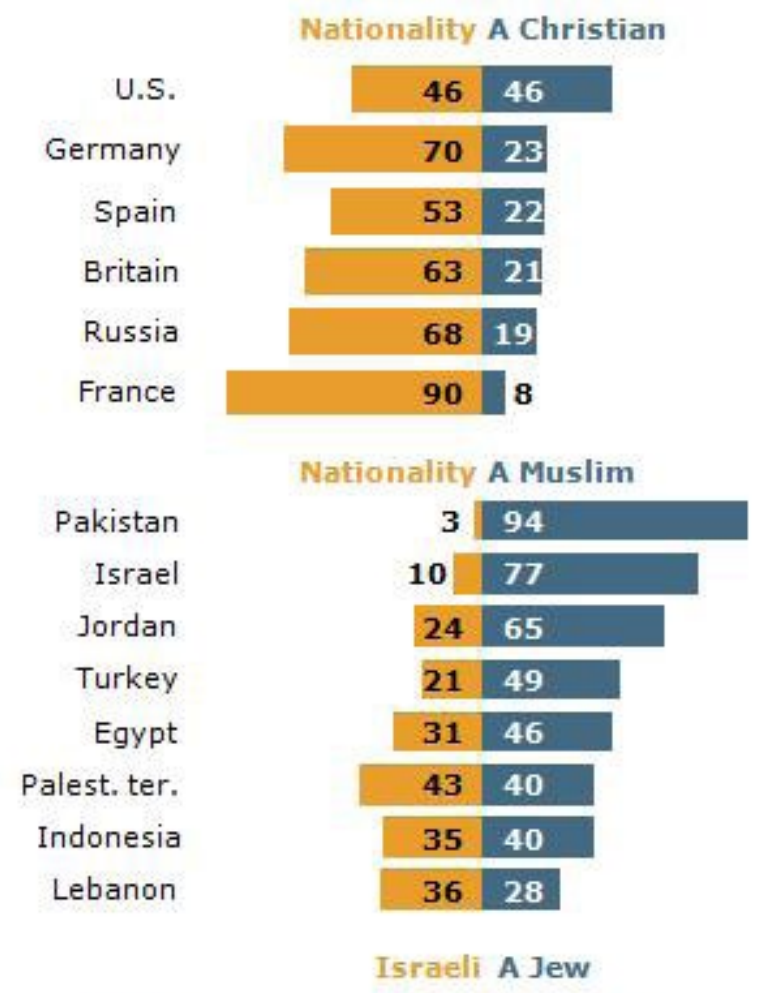

Israel

$22 \quad 57$

In the U.S, and Europe, figures are for Christians only. In

predominantly Muslim countries, figures are for Muslims

only. In Israel, figures are for Jews only.

PEW RESEARCH CENTER Q35chr, Q35mus \& Q35jew.

Figure 2: In the US \& Europe the figures are for Christians only while in remaining countries they are for Muslims only.

So-called 'Good Muslims', on the other hand, are perceived to be highly religious and family oriented. A 2001 British Home Office Citizenship Survey found that for British Muslims, family is the most important factor followed by religion while for British Christians, religion ranked seventh. (Choudhury 2007) When asked by Pew whether they consider themselves Muslim or British first, $81 \%$ of British Muslims picked Muslim while only 7\% picked British. (Choudhury 2007) A 2011 Pew Global Survey found that unlike Christians who consider themselves as French (90\%), Germans (70\%), Russians (68\%), British (63\%), Spanish (53\%), and Americans (46\%) first, most Muslims around the world consider themselves to be Muslims first (Figure 2). Thus instead of comparing themselves with the West on per-capita income or individual rights, they compare themselves with the West on the degree of devotion to their religion and culture and on the strength of their social ties with family and friends.

The United States has spent considerable resources in efforts to promote a more positive image in the Middle East through funding the National Endowment for Democracy (NED), Middle East Partnership Initiative (MEPI), and other programs (Sharp 2006). However, Middle Easterners appear to be less than impressed by US efforts. In fact the situation seems to be getting worse. The 2011 Pew Survey found that global Muslim perceptions of American and European hostility had actually increased since 2006, "with the percentage 


\section{Journal of Terrorism Research}

describing Americans as hostile rising 11 percentage points in Turkey and Pakistan, six points in Egypt, and five in Jordan... The view that Europeans are hostile has become more common since 2006 in Turkey $(+13$ percent), Jordan (+11 percent), Egypt (+7 percent), and Pakistan (+7 percent)." (PewGlobalAttitudesProject 2011)

In order to arrest these negative developments, we need to better understand how creative myths painstakingly weaved by social identity entrepreneurs, are contributing to the growth of anti-Western Jihadism among Muslims around the world. Just as we saw earlier with the social creativity strategy that resulted in a redefinition of African- and Latino-American males, the intense focus on the dimension of religiosity among Muslims has resulted in being a devout Muslims as the only acceptable way to be a good person. It is in this atmosphere that Jihadists find easy recruits. Far from providing Muslims an alternative to religious extremism and violence, socially creative ideologies actually prepare the fertile ground where radicalisation and Jihadism can flourish.

While social creativity is often seen from the perspective of an underprivileged minority group as the group's valiant struggle to construct a positive self-image (Galinsky, Hugenberg et al. 2003), it can also be seen from the perspective of the majority group as remoulding core social identity beliefs of a minority group. For example, by collectively stereotyping African-Americans as brutes and Jezebels, White Americans have been able to influence African-Americans to redefine their core social identity beliefs in what it means to be a good African-American (Powell 2011). This suggests that by understanding the social identity dynamics, a dominant group can affect core social identity beliefs of a marginalized group. This is contrary to the argument often offered as definitive conclusion by some social scientists that it is not possible for the West to positively affect core social identity beliefs of Muslims and that only other Muslims can engage in the battle of ideas against jihadists. It suggests that the West can actually play an active role in positively affecting the social identity beliefs of Muslims.

\section{Why Does the Jihadi Message Resonate With Some Muslims}

The jihadi message has been successful in motivating some Muslims to join a radical cause because it is a natural extension of the dominant narrative in the Islamic world. It follows the arcing pattern (Figure 3) that many successful messages of social change possess. (Upal, Packer et al. 2011) Arcing narratives acknowledge that a group is currently not doing well, remind the group of its glorious past, and promise that making a change to group's shared beliefs will restore that glory in the future. A series of studies have found that such narrative structure is more persuasive than other structures especially on those group members that identify strongly with the group and are especially resistant to most social change messages. (Upal, Packer et al. 2011) 


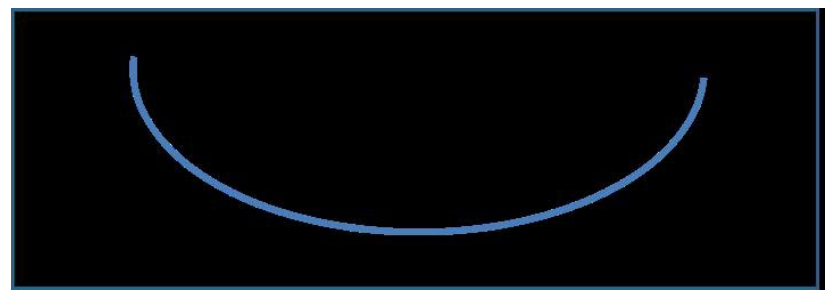

Figure 3: Arcing pattern of glorious-past-inglorious-present-glorious future that successfully overcomes a group's natural resistance to messages of change.

The key tenets of the Islamist narrative created and propagated by creative Islamic thinkers are as follows.

1. The world was a terrible place before Islam especially for the vulnerable such as women and orphans.

2. The arrival of Islam ushered in a golden era of human rights, prosperity, and happiness for all. The first Muslims strictly adhered to the tenets of Islam and were therefore rewarded by Allah with victory after victory over non-Muslims. This era lasted till the end of fourth Islamic caliphate.

3. After the era of strict compliance, Muslims moved away from Islam. As they did, Allah started taking away his blessings. While there were several valiant attempts to slow down societal degradation (e.g., Umar II), they were largely unsuccessful and the decay continued unabated. The low-point of Islam occurred when crusading colonial powers occupied Muslim lands. Those powers now control Muslims through oppressive puppet regimes who make decisions that favour the West.

4. Those who support the West and its puppet regimes in Muslims countries are not Muslims but apostates. Apostates who actively plot against Muslims deserve to be punished with death.

5. The only way to regain the lost Glory of Islam and to ensure a fulfilment of God's promise to Muslims of a final victory of Islam is to go back to strictly complying with tenets of Islam.

6. Consequently, the doctrine, institution, and culture of Jihad needs to be reconstituted to ensure a final victory of Islam.

As discussed earlier, the roots of the above narrative go back to the $13^{\text {th }}$ century and, at this point, it is so deeply embedded that a broad spectrum of Muslims regardless of their sectarian, social class, or political backgrounds generally agree with most of the above propositions (PewForum 2012, Moaddel 2014). These include members of heterodox movements such as Ahmadiyya Muslim Jama'at (Upal 2005), who disagree with 4 and 6 but agree with all of the remaining propositions. Thus the Jihadist message which affirms the above propositions only adds the proposition that "our organization is best suited to lead to the final victory of Islam.” The Jihadi Proposition resonates with most Muslims around the world despite their regional differences. This is because the Jihadist message is minimally counterintuitive for most Muslims and thus best suited to attract the target audience's attention and yet be sensible enough to be accepted by them (Upal 2014). A series of studies by Upal and colleagues (Upal 2014) found that people better remember those ideas that violate a small number of their expectations as compared to either ideas that do not violate any of their expectations or ideas that violate a large number of their expectations.

\section{Countering the Narrative of International Jihadi Movement}

While an increasing number of scholars and decision makers alike are beginning to recognize the need to counter the narrative of international Jihadi movement, the efforts to date have not been informed by a deep 


\section{Journal of Terrorism Research}

analysis of the social identity dynamics of Islamic societies. Most of our ad-hoc counter-narrative efforts on both social and traditional mass media focus on pointing out logical absurdities of Jihadist worldview (e.g., "so DAESH wants to build a future, well is beheading a future you want, or someone controlling details of your diet and dress?") but do not offer a well thought out comprehensive alternative narrative that can provide answers to the various issues facing Muslims around the world. Some argue that the task of defining and propagating a counter-narrative is best left to Muslims moderates. However, far from challenging the dominant Islamic narrative, most Muslim moderates currently being supported by the West, actually affirm most tenets of the dominant Islamist narrative while offering small modifications to 4 and 6 . The problem is that without challenging the beliefs that define what it means to be a good Muslim, suggestions by moderate Muslims that military Jihad is forbidden simply make them bad Muslims in the eyes of their fellow Muslims. Unfortunately, this loss of credibility means that such messages have little effect on its intended audience even though the messages themselves may sound great to the Western powers that fund or make them.

Another attraction of the Jihadist narrative is that it is comprehensive. It explains everything from the reason for the creation of the universe ("man was created to worship God") to why Muslim nations are so subservient to the dominance of the West ("because we've stopped following Islam") to what a good Muslim needs to do in the next five minutes ("worship God so that we can regain our past glory"). The moderate message, on the other hand, is limited to pointing out isolated passages from the Quran or Hadith that ask Muslims to be tolerant of others. Is it any wonder, then, that the moderates are so badly losing the war of ideas both among the Muslim youth in the West and among Muslims in Muslim countries? Washington Post Columnist Fareed Zakaria recently noted that, "no matter what the U.S. has done, Islamic radicalism has been on the rise for two decades." (Zakaria 2015) A 2006 Environics Institute Poll found that $73 \%$ of Canadian Muslims said that Toronto 18 attacks, if carried out would not have been justified. However, those between the ages of 18 to 29 were significantly more likely than older respondents to say that such attacks would have been justified. (Environics-Research-Group 2006)

A roundtable of counter-terrorism experts jointly organized by Hedayah (the International Center of Excellence for Countering Violent Extremism (CVE)) and the International Centre for Counter-Terrorism concluded that the Jihadist narrative is successful because it, "is easy to understand, adaptable, and has a strong emotional and religious appeal... Al-Qaeda's narrative also provides a clear solution (violence against the "enemy" to achieve its aims) to a real or perceived problem, which is often lacking in current counternarratives." (Hedayah 2014). Noticing the lack of a comprehensive alternative narrative, the experts argued that, "there is currently no sustainable or long-lasting effort to create and coordinate counter-narratives" and advocated the need to develop "attractive alternative narratives" to counter the Jihadist worldview. The problem is that as a result of efforts by Muslim revivalist movements (recounted above) Muslim identity has come to be defined in terms of one's blind devotion to religious doctrine and respect for opinions of older extended family members. This means that any Muslim who advocates individual rights or tolerance of others automatically comes to be considered a 'bad' Muslim or, even worse, a Western puppet and a traitor.

\section{A Effective Alternative Narrative of Islam}

What is needed today is an alternative narrative that is as comprehensive as the dominant Islamic narrative. We need a counter-narrative effort that doesn't just defensively challenge small fringe elements of the dominant Islamic narrative but also offers Muslims around the world an attractive alternative. Our counternarrative must satisfy their social psychological needs for positive self-esteem by telling them how they are 


\section{Journal of Terrorism Research}

better than others, yet undermine the need to violently confront those they consider their outgroups. It satisfactorily answers the "what went wrong" question and offers Muslims a non-violent course of action that they can follow to overcome their lower socioeconomic and political status. We also need strategies that allow the West to play an active role in hindering the growth of violent Jihadism.

While this is a challenging task, a focussed effort can succeed in developing such a narrative. Over the last century there have been numerous social movements in various parts of the Islamic world that have successfully challenged the traditional Islamic narrative. For varying periods of time such movements succeeded in making their narrative as the dominant view in their part of the world. This includes, for instance, the socialist movements in various Arab and non-Arab countries. The socialist movements sought to use social creativity by arguing that the reason for Muslim decline was to be found in Western Capitalist oppression of the poor (Ismael 2009). They argued that Islam's message at its core is about egalitarianism and equality. They traced the roots of their movement back to the prophet Muhammad who (along with his family) lived a life of poverty. Whenever he was given any gifts, he would promptly distribute them amongst the poor. His most prominent companions and successors, Abu-Bakr and Umar, instituted state support for the poor, guaranteeing a minimum living standard for all. When this started to change during the tenure of the third successor, Uthman, another companion of the prophet, Ab-Dhar al-Ghifari, protested against the accumulation of wealth by Uthman and his family (Esposito 1995). Islamic socialists argued that West believes in capitalism and inequality among people while egalitarianism and social welfare are Muslim values. Islamic socialism became the dominant narrative in many Muslim countries in the 1970s including Libya, Pakistan, Syria, Iraq, and Egypt.

While more work is needed to identify critical features of Islamic Socialism and other social movements that have defeated Islamism, one can see several reasons why it had some success. The socialists realized that in order for their ideology to succeed, they had to adopt the arcing narrative pattern used by the dominant Islamic narrative. They also had to get Muslims to believe that Islamic socialism went all the back to the start of their religion and was responsible for their glorious past (Paracha 2013). During the cold war, the West fought against the socialist narratives around the world. In Islamic countries this often meant supporting Islamists (e.g., the West supported the Islamists militarily in their civil war against the communists in Afghanistan). Unfortunately, Western anti-socialism efforts succeeded a little too well in the Islamic world because in wiping out the Islamic socialist narrative, they left the Islamic narrative as the dominant thought in much of the Muslim world.

The first step of a Research and Design effort to develop an alternative course of action must be to study the historical social movements that offered alternatives to the Islamist narrative and had some success in replacing it. We need to understand how these efforts were able to succeed and what needs to be done to replicate that success today. The second step of such an effort is to look at comprehensive alternative narratives that are being proposed currently by Islamic social identity entrepreneurs (Upal 2015) to identify the narratives that have the best chance of gaining widespread following and eliminating the threat of terrorism against the West. There are several such narratives in existence including those proposed by Muslim scientists such as the first Muslim scientist to win a Nobel Prize Dr. Abdus Salam. (Salam 1989) Muslim scientists argue that while Qur'an does emphasize worship, it also repeatedly exhorts its readers to think (e.g., Can't you see how the earth is laid flat? Can't you see how the moon and sun obey their orbits so perfectly?). In fact thinking and reflecting is one of the most frequently-mentioned commands in the Qur'an. Similarly, a much more plausible reason for the decline of the Islamic civilization is the decline of free thought, and its accompanying scientific and technological output. A successful counter-narrative should 


\section{Journal of Terrorism Research}

make it clear that if Muslims want to regain the glory of their early years, then they must educate themselves in modern science and technology. The benefit of this alternative narrative is that it also facilitates an active role for the West. For instance, Western governments can acknowledge the huge role that Islam played in the renaissance of science in Europe. This will, in turn, allow the Muslims to claim free-thinking and science as inherent strengths of the Islamic civilization.

Once we develop a scientifically-informed comprehensive alternative narrative, we must work with our Western allies as well as governments and community leaders in Muslim countries to propagate it as widely as possible. Just like the efforts to fight communism took decades, the fight against the international Jihadist movement will also take decades. However, selecting the most effective counter-narrative will ensure that the Jihadist narrative is slowly eroded over time.

\section{Conclusion}

If we are serious about fighting the international Jihadi movement, we have to counter the ideologies and narratives that support this movement. Without countering the underlying ideological basis of Jihadism, our counter-terrorism and counter-radicalization efforts will continue to fail. We must develop a research and fact-based approach to develop a comprehensive alternative narrative thereby countering this growing threat to our security.

About the author: Dr. M Afzal Upal is President of Al-Razi Centre. A cognitive scientist of religion with expertise in the Islamic social and religious movements, he has published more than 75 articles on cognitive science of religion, new religious movements, and cognition and culture. He was chair of the First International Workshop on Cognition and Culture, the 14th Annual Conference of the North American Association for Computational, Social, and Organizational Sciences and the AAAI-06 Workshop on Cognitive Modeling and Agent-based Social Simulation.

\section{Bibliography}

Akyol, M. (2011). Islam Without Extremes: A Muslim Case for Liberty. New York, NY, W. W. Norton \& Company.

Choudhury, T. (2007). The Role of Muslim Identity Politics in Radicalisation. London, UK, Department for Communities and Local Government.

el-Nawawy, M. (2006). "US Public diplomacy in the Arab world: The news credibility of Radio Sawa and Television Alhurra in five countries." Global Media and Commuication 2(2): 185-205.

Environics-Research-Group (2006). Focus Canada: The Pulse of Canadian Public Opinion. Ottawa, ON, Envrionics Research Group.

Esposito, J. (1995). Socialism and Islam. Oxford Encyclopedia of the Modern Islamic World. Oxford, UK, Oxford University Press.

Festinger, L. and H. Schachter (1964). When Prophecy Fails. New York, Harper Torch Books.

Funk, N. C. and A. A. Said (2004). "Islam and the West: Narratives of conflict and transformation." International Journal of Peace Studies 9(1): 1-28. 


\section{Journal of Terrorism Research}

Galinsky, A. D., et al. (2003). “The reappropriation of stigmatizing labels: Implications for social identity.” Identity Issues in Group- Research on Managing Group and Teams 5: 221-256.

Haslam, A., et al. (2005). "Social identity and the dynamics of leadership: Leaders and followers as collaborative agents in the transformation of social reality." Leadership Quarterly 16: 547-568.

Hedayah (2014). Developing Effective Counter-Narrative Frameworks for Countering Violent Extremism. Hague, Hedayah: The International Center of Excellence for Countering Violent Extremism \& The International Centre for Counter-Terrorism at The Hague.

Hogg, M. A. and G. M. Vaughan (2002). Social Psychology. London, UK, Prentice Hall.

Ismael, T. Y. (2009). The Communist Movement in the Arab World. New York, NY, Routledge.

Lewis, B. (2003). What went wrong? The clash between Islam and modernity in the Middle East. New York, Harper Perennial.

Moaddel, M. (2014). Modalities of National Sovereignty: Territorial Nationalism versus Islamic Fundamentalism in Muslim-Majority Countries. Ann Arbor, Michigan, Population Studies Center, University of Michigan

Mummendey, A. and H. J. Schreiber (1984). "'Different" just means "better": Some onvious and some hidden pathways to in-group favouritism." British Journal of Social Psychology 23: 363-368.

Paracha, N. F. (2013). Islamic Socialism: A history from left to right. Dawn. Karachi, Pakistan, Dawn.

PewForum (2012). Religious Beliefs and Practices.

PewGlobalAttitudesProject (2011). Muslim-Western Tensions Persist. Washington, DC, Pew Research.

PewGlobalSurvey (2014). Global Opposition to US Surveillance and Drones, but Limited Harm to America's Image.

Powell, V. (2011). “A Social identity framework of American hip-hop cultural performance." Social Identities 17(4): 459-476.

Salam, A. (1989). Ideals and Realities: Selected Essays of Abdus Salam. Singapore, World Scientific Publishing Company.

Sharp, J. M. (2006). US Democracy Promotion Policy in the Middle East: The Islamist Dilemma. CRS Report for Congress, CRS.

Tajfel, H. and T. J. Turner (1985). An integrative theory of intergroup conflict. Psychology of intergroup relations. S. Worchel and W. Austin. Chicago, Nelson-Hall.

Tajfel, H. and T. J. Turner (1986). The social identity theory of intergroup behavior. Psychology of Intergroup Relations. S. Worchel and L. W. Austin. Chicago, IL, Nelson Hall.

Taylor, D. (2002). The Quest for Identity: From Minority Groups to Generation Xers New York, NY, Praeger.

Upal, M. A. (2005). “Towards A Cognitive Science of New Religious Movements." Cognition and Culture 5(2): 214-239.

Upal, M. A. (2014). “Three Practical Lessons from the Science of Influence Operations Message Design.” Canadian Military Journal 14(2): 53-58.

Upal, M. A. (2015). A Framework for Agent-based Social Simulations of Social Identity Dynamics. Conflict and Comlexity: Understanding Complex Systems. P. von Fellman. Berlin, Springer Verlag. 


\section{Journal of Terrorism Research}

Upal, M. A., et al. (2011). Investigating the Dynamics of Identity Formation, and Narrative Information Comprehension: Final Report Defence Research \& Development Canada.

van Knippenberg, D. (1978). Status differences, comparative relevance, and intergroup differentiation. Differentiation between social groups: Studies in the social psychology of intergroup relations. H. Tajfel. London, Academic Press: 171-199.

Zakaria, F. (2015). US Intrevention is not the answer. Washington Post. Washington, DC, Washington Post. 